\title{
Analysis of Mobile Commerce in the SMEs of the European Union
}

\author{
Luis FERNÁNDEZ SANZ, Josefa GÓMEZ PÉREZ, Ana CASTILLO-MARTINEZ*, Sanjay MISRA
}

\begin{abstract}
This paper examines the situation of e-commerce and m-commerce in SMEs in the European Union and analyses if their behaviour in this field is determined by a series of factors, such as the size of the company, the type of business, turnover, etc. which may also influence their needs of specific training for their employees. This study is based on an online survey responded by 674 SMEs from eight different countries in Europe, aimed at providing training assistance to SMEs to support their efforts towards m-commerce. The objective is the analysis of the skills and knowledge to be recommended to employees of SMEs for a better preparation to implement the companies' strategy of $\mathrm{m}$-commerce. Although analysis of results from survey has supported the initial goal of developing training courses for m-commerce which include different economic, legal and technical topics, it has mainly provided very relevant conclusions on the factors which impact the adoption of e-commerce and m-commerce by SMEs.
\end{abstract}

Keywords: e-commerce; European Union; market; m-commerce; SME; survey

\section{INTRODUCTION}

The recent advances in wireless and mobile technologies have changed our daily habits in many aspects and commerce is not an exception. Nowadays, most users have Internet connection, which allows the access to ecommerce to most of them. It is important to keep in mind that mobile systems, such as smartphones, have become the primary computing platform for many users [2]. Therefore, it is not surprising that the original e-commerce has adapted to the new times with the appearance of the Mobile Commerce, also known as m-commerce.

The rise of this sort of commerce has been studied for many researches in different areas. However, if we deeply browse the literature contributions, most of them are focused on technical aspects, mainly in the security field like in [22] where different mobile payments were analysed, or the one in [26], which analyses the security of credit card transactions. Also, Cozzarin and Dimitrov found in [5] that perceived risk affects purchase decisions for mobile users more than PC users, and Chen presented the architectures and modes of secure media distribution in $\mathrm{m}$-commerce environment in [4]. Usability is another factor mostly addressed in contributions focused on $\mathrm{m}$ commerce [16, 32, 43]. Other researchers have progressed further and present an evaluation of this sort of commerce made from the customer perspective [41], or even evaluating the quality of the service [29] or studying the infrastructure success factors [17]. However, when the search is focused on studies about the adoption of $\mathrm{m}$ commerce, especially in cases of Small and Medium sized Enterprises (SME), the number of contributions is limited.

If we also analyse contributions on the adoption of ecommerce, the number of references is really high. This fact is not surprising considering that e-commerce is the precursor of m-commerce. Focusing on the specific studies based on the adoption of the e-commerce on SMEs it is possible to observe different approaches. Some of those works, as the one presented in [18] conduct the study through different surveys inspired in the market situation. Others like [14] present a model to predict SME's decisions to achieve a competitive advantage. Another group of studies such as [36] are focused on the analysis of the barriers to e-commerce. Finally, contributions like [8] or
[42] are aimed at identifying the success factors for this type of commerce in SMEs.

However, it is important to add the particularities of each country as a key factor when investigating the progress of e-commerce in SMEs. This is the reason why it is possible to find varied contributions focused on the adoption of e-commerce in specific countries, especially in emerging markets comparing different countries [15] or focusing in specific cases like [28], Malaysia [25], Turkey [19], India [39] or Indonesia [33] among others. Nevertheless, the studies performed in a multinational environment or in a wide group of countries, as the European Union, are scarce, perhaps because it is much more difficult to have the opportunity of coordinating the analysis activities.

In our case, we carried out a study on the skills and knowledge required to perform $\mathrm{m}$-commerce tasks in order to develop training courses as complete as possible. As shown in [38], the availability of those skills is essential for planning successful e-commerce projects. We assumed that there could be a large variety of scenarios in European SMEs and the situation of each could deeply impact the perception of training needs and the development of the mcommerce activity itself. So, the first step was the generation of an online survey as well as the analysis of 50 case studies. This first analysis was focused simultaneously on two main aspects: firstly, their status of development regarding the e-commerce and the $\mathrm{m}$ commerce and their characteristics (e.g. company size, turnover, type of business); secondly the expression of their preference for training topics for their employees to be prepared for $\mathrm{m}$-commerce.

The rest of the paper is organized as follows: the conducted survey is described in Section 2 and the methodology of data collection is shown in Section 3. The analysis of the results is presented in Section 4 while there is a discussion of the study in Section 5. Finally, Section 6 presents conclusions and future line of action.

\section{SURVEY DESIGN}

The survey was targeted to SMEs interested in $\mathrm{m}$ commerce strategies and first possible solutions for $\mathrm{m}$ commerce implementation. The survey was complemented 
by the previous collection of best practice examples from SMEs of different EU countries through the documentation of 50 case studies presenting already existing and successful m-commerce solutions. This information helped us in shaping some of the questions of the survey to address specific interesting aspects to be analysed: e.g. demands of training and some categorization aspects of businesses.

The results of our analysis of relevant literature have clearly confirmed that there is still much room for study in the field of the mobile commerce: especially in what is referred to the implication of SME in this activity as well as to the factors which impact such activity including the need of training for employees. The study developed was aimed at firstly analysing the situation of companies regarding e-commerce in general and mobile commerce, while collecting their needs of training for their employees in a wide perspective, not explicitly related to technical aspects. In this study, a survey has been launched addressed only to European SMEs that expressed some interest in implementing $\mathrm{m}$-commerce activities. According to the European Ecommerce Association, the
European e-commerce turnover of SMEs increased by $12.75 \%$ to $€ 540$ billion in 2017 [7]. The research goals related to the study on m-commerce in SMEs were the following:

- RG1: To assess and characterize the SMEs' situation regarding the e-commerce and $\mathrm{m}$-commerce context.

- RG2: To determine which factors (such as size of the company, type of business, turnover, etc.) may mpact the implementation of $\mathrm{m}$-commerce activities.

- RG3: To determine the needs and requirements of SMEs to plan and prepare training curricula.

The survey was targeted to qualified representatives of SME to ensure that people responding have the requested information: e.g. data on business operations, visitors, etc. The survey link was not universally submitted to anyone in a SME but to specific managers and specialists. The method for delivering the invitation to answer questions was devised to be sure that only one representative of each company was answering questions, avoiding opinions from several persons from the same company. The questions are shown in Tab. 1.

\begin{tabular}{|c|c|c|}
\hline (2) & Type of question & Possible values \\
\hline (Q01) What type of business does your company run? & Single choice question & $\begin{array}{l}\text { Consultant/Service } \\
\text { Retailer/Merchant store } \\
\text { Production } \\
\text { Other }\end{array}$ \\
\hline (Q02) What kind of products are sold in your web shop? & Single choice question & $\begin{array}{l}\text { Services } \\
\text { Goods } \\
\text { Other } \\
\end{array}$ \\
\hline (Q03) Who are your customers? & Single choice question & $\begin{array}{l}\text { B2C (Business to Consumer) } \\
\text { B2B (Business to Business) }\end{array}$ \\
\hline (Q04) What delivery methods does your company provide? & Single choice question & $\begin{array}{l}\text { E-Mail } \\
\text { Regular Shipping } \\
\text { Express Service } \\
\text { Online downloads } \\
\text { Other }\end{array}$ \\
\hline (Q05) How many employees does your company have? & Single choice question & $\begin{array}{l}1 \text { - } 10 \text { employees } \\
11-49 \text { employees } \\
50-249 \text { employees } \\
\geq 250 \text { employees } \\
\end{array}$ \\
\hline (Q06) What is the annual turnover of your business? & Single choice question & $\begin{array}{l}0-1 \text { Mio } € \\
1-2 \text { Mio } € \\
2-10 \text { Mio } € \\
10-50 \text { Mio } € \\
>50 \text { Mio } €\end{array}$ \\
\hline (Q07) Does your company use a web shop? & Yes/No question & Yes/No \\
\hline (Q08) What kind of web shop does your company use? & Single choice question & $\begin{array}{l}\text { Open source } \\
\text { Third party web shop } \\
\text { Outsourced }\end{array}$ \\
\hline (Q09) What kind of web shop-analytic-tool do you use? & Open question & \\
\hline (Q10) Is your web shop optimized for mobile users? & Yes/No question & $\begin{array}{l}\text { Yes } \\
\text { No } \\
\text { N/A }\end{array}$ \\
\hline (Q11) Are you planning to build a new/different web shop in the next 12 months? & Yes/No question & $\begin{array}{l}\text { Yes } \\
\text { No } \\
\text { N/A }\end{array}$ \\
\hline $\begin{array}{l}\text { (Q12) How much turnover (in percentage terms of your whole turnover) is made by } \\
\text { the web shop? }\end{array}$ & Single choice question & $\begin{array}{l}0-10 \% \\
10 \%-20 \% \\
21 \%-30 \% \\
31-40 \% \\
41-50 \% \\
>50 \% \\
\text { Don't Know }\end{array}$ \\
\hline (Q13) How many unique visitors does your web-shop have per week? & Single choice question & $\begin{array}{l}1-100 \\
101-1000 \\
>1000 \\
\text { Don't Know }\end{array}$ \\
\hline
\end{tabular}


Table 2 Questions of the survey (continuation)

\begin{tabular}{|c|c|c|}
\hline Question & Type of question & Possible values \\
\hline $\begin{array}{l}\text { (Q14) How many customers visit your web shop using a mobile device (smartphones } \\
\text { and tablets) in percentage terms of all visits? }\end{array}$ & Single choice question & $\begin{array}{l}0-10 \% \\
10 \%-20 \% \\
21 \%-30 \% \\
31-40 \% \\
41-50 \% \\
>50 \% \\
\text { Don't Know }\end{array}$ \\
\hline $\begin{array}{l}\text { (Q15) How many of these "mobile" visitors (in percentage terms of all mobile } \\
\text { visitors) are driven by social media platform? }\end{array}$ & Single choice question & $\begin{array}{l}0-10 \% \\
10 \%-20 \% \\
21 \%-30 \% \\
31-40 \% \\
41-50 \% \\
>50 \% \\
\text { Don't Know }\end{array}$ \\
\hline (Q16) How many orders do you make per week on your web shop? & Single choice question & $\begin{array}{l}1-100 \\
101-1000 \\
>1000 \\
\text { Don't Know }\end{array}$ \\
\hline $\begin{array}{l}\text { (Q17) How many orders do you have per week from mobile users (in percentage } \\
\text { terms of your total orders) }\end{array}$ & Single choice question & $\begin{array}{l}0-10 \% \\
10 \%-20 \% \\
21 \%-30 \% \\
31-40 \% \\
41-50 \% \\
>50 \% \\
\text { Don't Know }\end{array}$ \\
\hline $\begin{array}{l}\text { (Q18) How many of these "mobile" orders (in percentage terms of your mobile } \\
\text { orders) are generated from social media traffic? }\end{array}$ & Single choice question & $\begin{array}{l}0-10 \% \\
10 \%-20 \% \\
21 \%-30 \% \\
31-40 \% \\
41-50 \% \\
>50 \% \\
\text { Don't Know }\end{array}$ \\
\hline (Q19) What kind of training in e-commerce do you need? & Open question & \\
\hline (Q20) Do you or one of your employees want to participate in the training pilot? & Yes/No question & $\begin{array}{l}\text { Yes } \\
\text { No } \\
\text { Maybe }\end{array}$ \\
\hline
\end{tabular}

The first part of the survey (questions 1 to 6 ) is designed to analyse the business characteristics: the type of business (Q01), the kind of products that are sold (Q02) and who the costumers are (Q03). These questions serve to delimit business scope adopting the approach followed in other similar studies $[18,19,28,35,40]$. In addition, these characteristics act as company influence driven by the nature of what is sold [1]. Moreover, we decided inquiring about the delivery methods of the company (Q04) to check if there is a connection with the previous questions. Of course, size and other standard indicators of the company should be also analysed to complete the picture of each company, especially when dealing with SME. We requested information on the workforce of the company in (Q05): this is a feature applied in works like $[1,18,40]$ to model its impact in the e-commerce activity. Another standard business indicator like annual turnover is also collected through the question Q06, as other studies have done before [40].

Obviously, a survey on e-commerce should address some basic questions to know the context where the respondent company is working in terms of relation to ecommerce. This is addressed in the second and main set of questions (Q07-Q18) of the survey. The first point to be checked is the existence of a web shop, which is a very relevant question (Q07) as seen in similar studies [18, 19, $28,42]$. We decided to add a question about the technical nature of the web shop (Q08) (open source, outsourced or third party) for forming the value of the answers to Q07 as it represents an indicator on the approach to e-commerce adopted by the company. Analytic web tools (i.e. Google
Analytics) are a helpful resource for the company, since they improve information and performance $[11,20]$; hence, we added a question on analytics to the survey (Q09) to complete the identification of the key elements which define the technical support to the commerce functionality.

Moreover, addressing our primary goal of focusing on $\mathrm{m}$-commerce requires asking whether the web shop was optimized for mobile devices (Q10) given the users' complaints found out in previous studies [31] as well as the need of connecting this to the perspectives of the company to build a new web shop (or improve their current one) (Q11): this is one of the factors which may impact success in general e-commerce identified by specific studies (e.g. [42]).

Going further from a very general depiction of their general situation, it was essential to determine the specific situation of each company regarding e-commerce and $\mathrm{m}$ commerce. Thus, apart from the turnover of the company, it was highly relevant to determine the percentage of it generated via the web-shop (Q12) as it is an indicator frequently used in related studies to determine the degree of evolution of the e-commerce [31, 40, 42]. Another relevant indicator to analyze the evolution of a company in the field is the number of weekly (unique) visitors (Q13) also used in different studies [10,11,12] and obviously how many of them accessed from mobile devices given our focus on m-commerce (Q14) [35]. It is also relevant to inquire about how many of these mobile visitors are driven by social media platforms (Q15) because other studies have detected this link between both worlds $[3,21]$. However, not only visitors are relevant. If we want a clear picture of 
the commerce situation of the SME, we need to know how many orders are placed per week (Q16) [42] having the possibility of determining which ones came from mobile devices (Q17) [30, 42] and again how many of these mobile orders are driven by social media platforms (Q18) [21].

Finally, as a goal of the study, we were very interested in the needs of specific training that SME think they would need for their employees to ensure they are prepared to contribute to the success of $\mathrm{m}$-commerce initiatives in the company. According to [23, 38], the lack of ICT knowledge/experience of the employees is identified as a barrier for adoption of e-commerce. The open question (Q19) has a two-folded goal: inspiring the kind of training that the project had to offer to SMEs and knowing what the weaknesses of their e-commerce/m-commerce activities are according to their perception [37]. Although there were some already identified key areas of training, we preferred to let the companies express in an open and free manner their needs of training for their employees to ensure they effectively support their efforts in m-commerce. Afterwards, we linked all the answers and the previously identified key areas. As the aim of the study was to develop learning resources for training course on $\mathrm{m}$-commerce, the last question (Q20) was related to the intention of respondents in participating in a training pilot.

\section{DATA COLLECTION}

The sampling technique within European Union SMEs for the survey was based on a stratified process which was mainly targeted to organizations which expressed some more explicit interest than the average in e-commerce. As a consequence, we could observe in the sample (see Tab. 2) a bigger proportion of SME that already have a webshop than the percentage deducted from regular European statistics [6], except for Austria and United Kingdom, showing similar rates in both cases. The same occurs when we observe the average percentage of web shops (see Tab. 2), where the difference between European statistics [6] and these results is more noticeable. As stated previously, the explanation for this is the process for selecting the sample from SMEs prone to act in e-commerce. This could represent a limitation of the present analysis and should be considered in future studies.

Table 3 Percentage of SMEs with a web shop and turnover (average percentage) of SMEs' web shops

\begin{tabular}{|c|c|c|c|c|}
\hline \multirow{2}{*}{ Country } & \multicolumn{2}{|c|}{ SMEs with web shop } & \multicolumn{2}{|c|}{ SMEs' web shop average turnover } \\
\hline & Europe & m-Commerce Project & Europe & m-Commerce Project \\
\hline Austria & $19 \%$ & $27.4 \%$ & $2 \%$ & $9.28 \%$ \\
\hline Macedonia & $3 \%$ & $23.1 \%$ & N/A & $36.66 \%$ \\
\hline Sweden & $32 \%$ & $29.2 \%$ & $6.5 \%$ & $34.33 \%$ \\
\hline United Kingdom & $23 \%$ & $22.7 \%$ & $4.0 \%$ & $45.0 \%$ \\
\hline Slovenia & $19 \%$ & $45.6 \%$ & $2.0 \%$ & $27.30 \%$ \\
\hline Romania & $9 \%$ & $38.8 \%$ & N/A & $33.33 \%$ \\
\hline Spain & $21 \%$ & $42.0 \%$ & $3 \%$ & $21.66 \%$ \\
\hline Italy & $8 \%$ & $27.2 \%$ & $1.5 \%$ & $18.75 \%$ \\
\hline
\end{tabular}

The survey was sent to 800 potential participants although the final number of completed responses was 674 $(84.25 \%)$. Respondents' locations were distributed among the following countries: Italy (29.97\%), Austria (14.09\%), Spain (13.06\%), Macedonia (11.57\%), Sweden (10.68\%), Slovenia $(10.09 \%)$, Romania $(7.27 \%)$ and United Kingdom $(3.26 \%)$.

Regarding the questionnaire execution, anonymous data collection was applied, announcing potential respondents that they would need five minutes of expected duration to complete the survey. In addition, the survey was available in eight different languages (corresponding to the ones of the project partners) and addressed to decision-makers/managers in SMEs. The online survey platform was powered by LimeSurvey.

\section{RESULTS}

The analysis of the results starts with the basic question of the use of web shop (shown in Fig. 1) where we can appreciate more web shops in Business to Consumer (B2C) activity models than in Business to Business (B2B): this could be justified by the fact that B2B are still less developed in the e-commerce approach of SMEs although it seems it is growing very rapidly according to researches provider [9, 24], expecting doubling B2C in 2020. In Tab. 3 we also see that the actual trend is an increasing percentage of web shops according to the size of the company: it goes from a $28 \%$ in micro-SMEs (less than 10 employees) to $42 \%$ in SMEs with 50 - 249 employees. SMEs with more than 250 employees are labelled as big companies and we appreciate that $38.5 \%$ of them have a web shop. This upward trend is quite similar when we refer to turnover indicators: the higher the turnover is, the higher the percentage of companies with web shops.

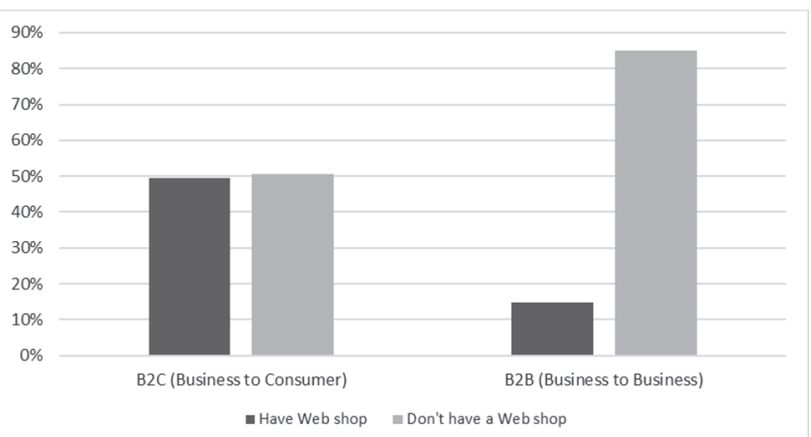

Figure 1 Type of customers (Q03) vs existence of web shop (Q07)

Besides, the data on the type of web shop implementation adopted by SMEs reveal that the majority is based on open source solutions (45.24\%) while outsourced $(40 \%)$ and third-party $(14.76 \%)$ complete the range of options. However, we cannot establish a trend based on the size of the company; except for the biggest companies in the study ( $>250$ employees) and those with 
the highest turnover $(>10 \%)$ which work without thirdparty web shops. It should be also noted that there are not relevant differences in technical solution when looking at the type of business activity (retail, services, and products, among others). Furthermore, we can define four major delivery methods provided by companies: regular shipping $(33 \%)$, express service $(33 \%)$, e-mail $(12 \%)$ and online downloads $(10 \%)$.

Table 4 Percentage of SMEs (with employees' breakdown) with web shops Percentage of companies (SME breakdown) with web shops

\begin{tabular}{|c|c|}
\hline Percentage of companies (SME breakdown) with web shops \\
\hline $1-10$ employees & $28.0 \%$ \\
\hline $11-49$ employees & $38.7 \%$ \\
\hline $50-249$ employees & $42.0 \%$ \\
\hline$\geq 250$ employees & $38.5 \%$ \\
\hline
\end{tabular}

These results do not reveal significant differences based on company size, on type of business (B2B or B2C) or on turnover. Nevertheless, we have identified a relationship between the delivery method and the type of business and kind of sold products: for example, service companies have a minimum quantity of physical deliveries $(3.26 \%)$ when looking at the average numbers, something logical.

In terms of reported turnover made by the web shops, we found that most of the companies selling goods (35.81\% of the total, $49.68 \%$ of their sector) declared less than $10 \%$ of total turnover coming from e-commerce, compared to those selling services $(7.44 \%$ of the total, $26.66 \%$ of their sector). Neither the differences related to $\mathrm{B} 2 \mathrm{~B} / \mathrm{B} 2 \mathrm{C}$ nor related to size of the company were found in this indicator of percentage of turnover. One exception appeared in micro-SMEs, where the proportion of $>50 \%$ of reported e-commerce turnover is higher than in other sizes of companies: this happens when micro-SMESs are defined by number of employees $(81 \%$ of SMEs with $>$ $50 \%$ of web shop turnover has less than 10 employees) and by annual turnover of the business ( $85 \%$ of SMEs with $>$ $50 \%$ of web shop turnover annually reported less than 1 $\mathrm{M} €$ ). Clearly, production-based businesses are less implied in e-commerce while the rest of types of companies are very similar in percentage.

Regarding web shop unique visitors, the results show the following numbers by ranges: 1 - 100 visitors (37\%), $101-1000$ visitors $(31 \%),>1000$ visitors $(19 \%)$ and unawareness of the number of visitors $(13 \%)$. Clustered results show similarities with regard to $\mathrm{B} 2 \mathrm{~B} / \mathrm{B} 2 \mathrm{C}$ clients, company size and turnover. Nevertheless, there are differences when dealing with production-based companies: they show a lower number $(1-100)$ of unique visitors $(11.71 \%$ of the companies) compared to the average number of companies with $1-100$ unique visitors (8.9\% of the companies).

Q10 (web optimized for mobile) is a question intimately related to Q14 (mobile visitors) as it shows the importance given by SMEs to having an optimized and user-friendly web shop. These two questions could help to evaluate the interest in adapting the main asset for $\mathrm{m}$ commerce, which is the web shop. According to the results (see Fig. 2), those SMEs which have an optimized web shop for m-commerce, have more visitors and, therefore, more possibilities to stimulate a purchase. The percentage of SMEs with optimized web shop varies between $42.3 \%$ and $76.9 \%$. Generally, those SMEs already with web shop tend to invest more in the adaption to mobile when their number of users accessing with mobile devices is higher. We do not know if having an adapted shop attracts more users with mobile devices or if the existing users are progressively using more their mobile devices, or if SMEs optimize their web shops only when they realized that they have more mobile users/visitors. This result is aligned to previous findings, e.g. the study [27] found that utilitarian factors had a negative effect on the consumption experience of consumers and that media richness was as important as subjective norms, and more important than convenience and self-efficacy. In addition, according to [34], from the customer's point of view, a satisfactory experience may determine their willingness to repeat it. Thus, it is vital to ensure that their first experience of a transaction is positive.

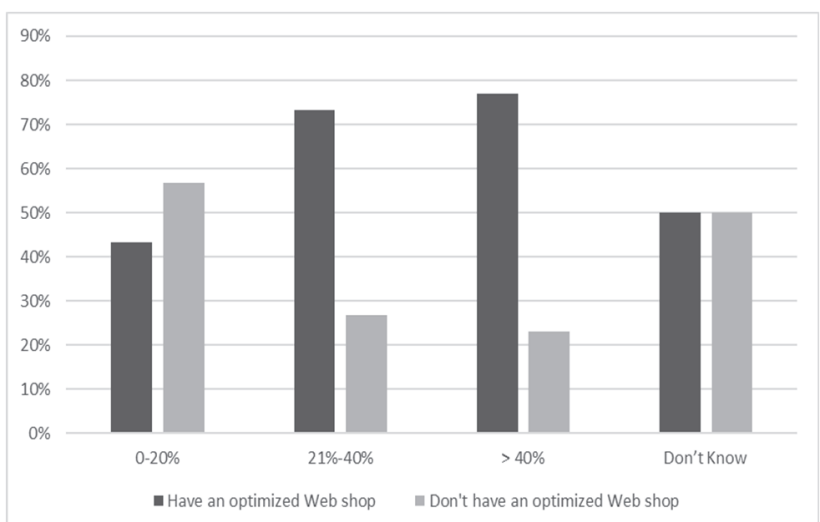

Figure 2 Number of mobile visitors (Q14) vs optimized web shop (Q10)

Fig. 3 shows the relationship between questions Q17 (orders form mobile) and Q10 (web optimized for mobile). Having an optimized web shop for mobile visitors does not directly imply increasing the number of orders per week from mobile users. This could seem a contradiction, but users normally visit the optimized web shops through the smartphones just for a visualization of the products and later they proceed to purchase through their computers. This might happen due to the lack of trust in conducting transactions through the phone, or because the purchase pages are better optimized for computers. This hypothesis is confirmed if we look at the average of visits using mobile devices $(24.1 \%)$ compare to the lower average of orders $(14.6 \%)$ from mobile users.

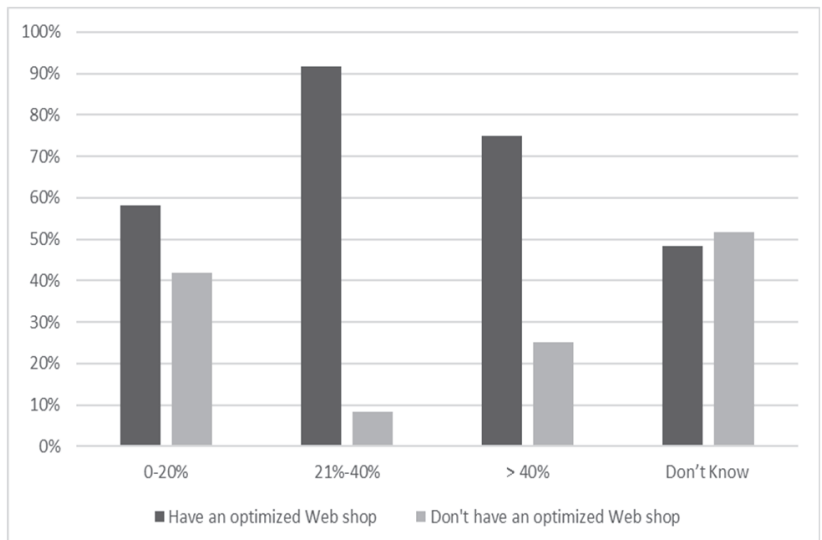

Figure 3 Weekly mobile orders (Q17) vs optimized web shop (Q10) 
Considering the absolute data, we can also see in Fig. 4 that a vast majority of SMEs reported less than 100 orders per week. The descending rate is much higher in the case of Q16 (orders per week) than in the case of Q13 (unique visitors per week).

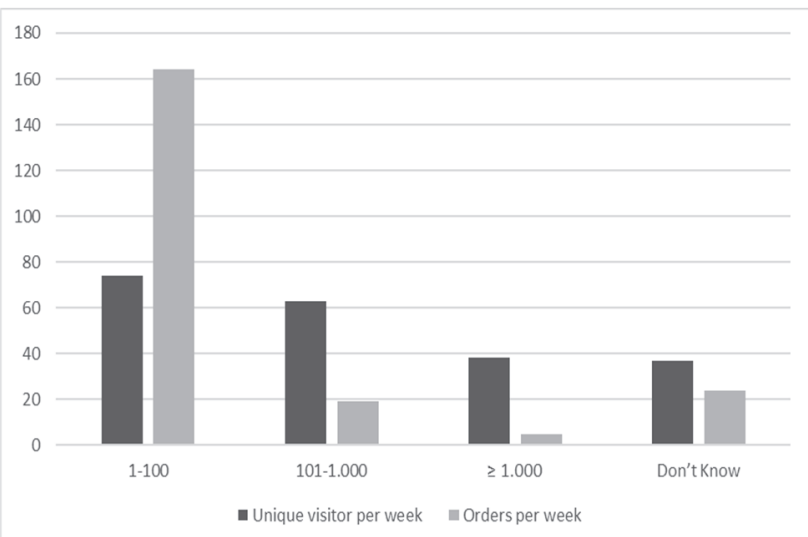

Figure 4 SMEs per ranges of unique visitors (Q13) and number of orders (Q16)

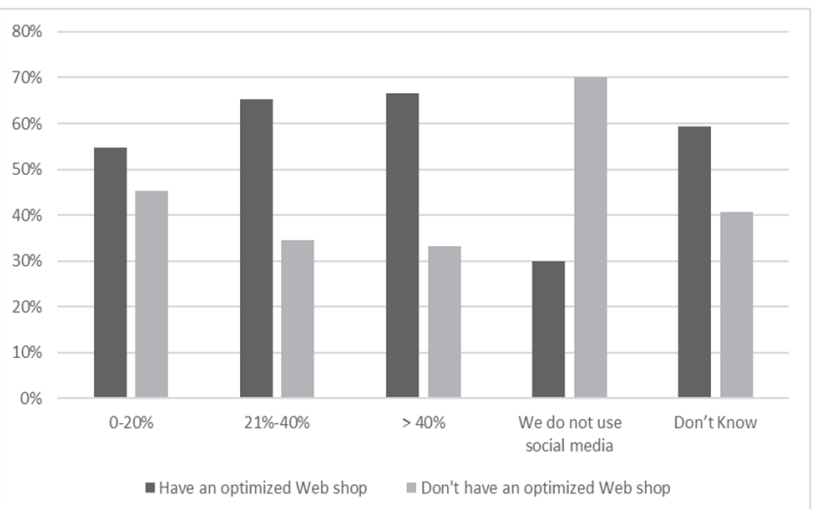

Figure 5 Percentage of mobile visitors coming from social media (Q15) vs optimized web shop (Q10)

Social media and mobile devices are two rapidly evolving technologies that SMEs can use to reach customers anytime anywhere. Thus, social media are increasingly used on mobile devices and they emerge as a powerful tool for m-commerce. According to Fig. 5, when the web shop is optimized, the percentage of visitors driven by social media platforms rises: that percentage for SMEs with a web shop optimized for mobile varies between $54.7 \%$ and $66.7 \%$. This is a logical result since the relationship between mobile devices and social media is very strong. It seems that SMEs are noticing that investing in this part of the business is profitable.

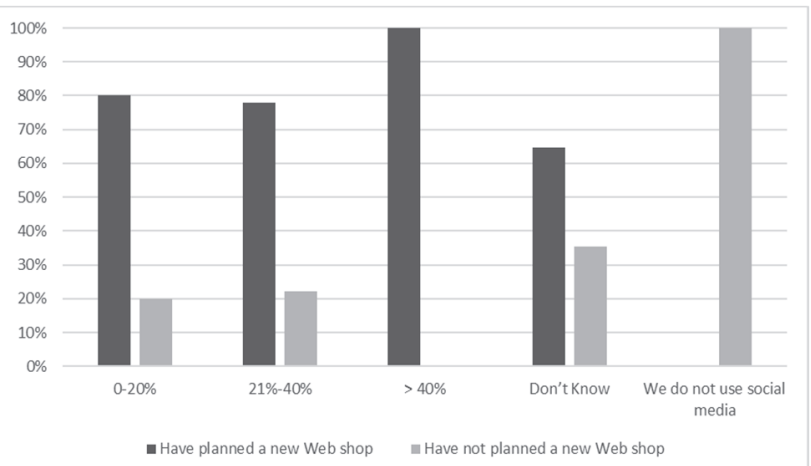

Figure 6 Percentage of mobile visitors coming from social media (Q15) vs SMEs which planned a new web shop (Q11)
Another trend within SMEs is to renovate/optimize the current web shops of companies. According to the results of Q11 (planning of new web-shop), the 29\% of SMEs which reported in Q07 (existence of web-shop) not having a web shop, were planning to build one in the next twelve months. Moreover, those SMEs that report more than $40 \%$ of mobile visitors driven by social media are planning to build a new web shop (see Fig. 6). This is quite logical considering that in this case the answers are restricted to SMEs which do not have a web shop at the time of responding the survey.

Fig. 7 reflects that the more customers visit the web shop, the higher is the number of SMEs which are planning to renovate the web shop.

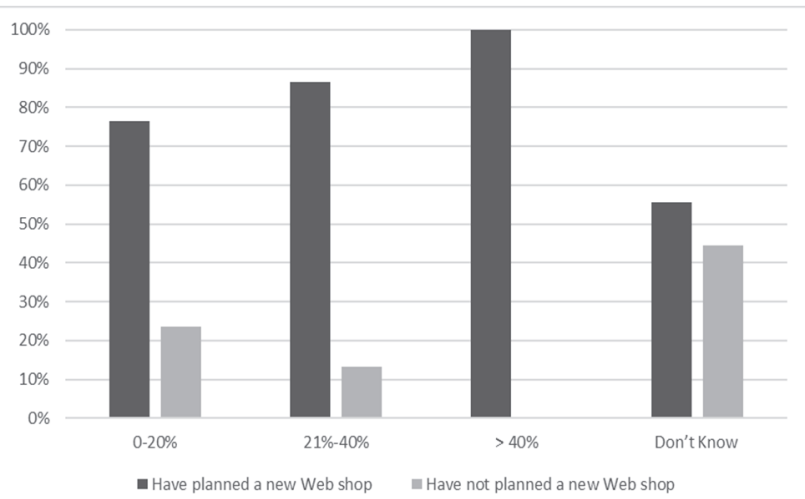

Figure 7 Percentage of mobile visitors (Q14) vs SMEs planning a new web shop (Q11)

Fig. 8 indicates that the $100 \%$ of SMEs which report having more than $20 \%$ of orders from mobile users per week are planning to renovate their web shops.

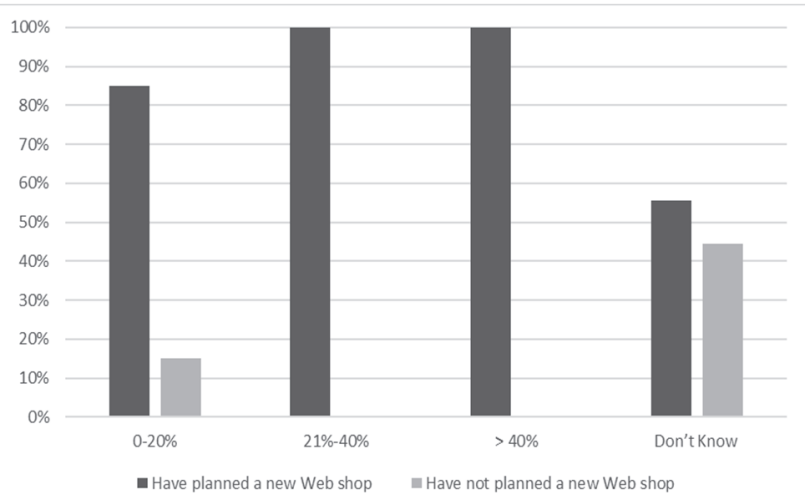

Figure 8 Weekly mobile orders (Q17) vs planned new web shop (Q11)

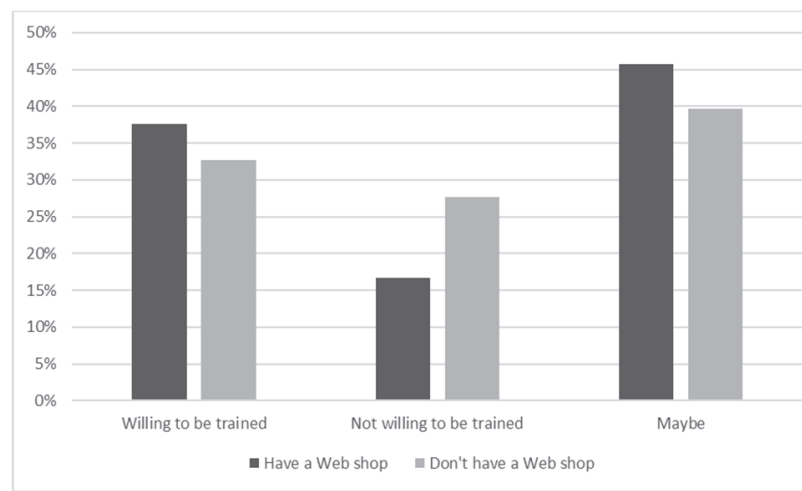

Figure 9 Employees willing to be trained (Q20) vs existence of web shop (Q7) 
After analysing the impact of the different factors on the results, actions and attitude of SMEs towards mcommerce, we must concentrate on the analysis of RQ3 and the training needs. Questions on training priorities (Q14) and interest on pilot courses (Q20) are the main source of information for this part. As shown in Fig. 9, most of the respondents say that they want their employees in the training pilot independently of whether their companies use a web shop or not.

According to Fig. 10, companies that are planning to build a new or different web shop in the next 12 months are more interested in participating in the training pilot that those which are not. On the contrary, companies that are not planning it do not want to participate in the courses. These are logical results.

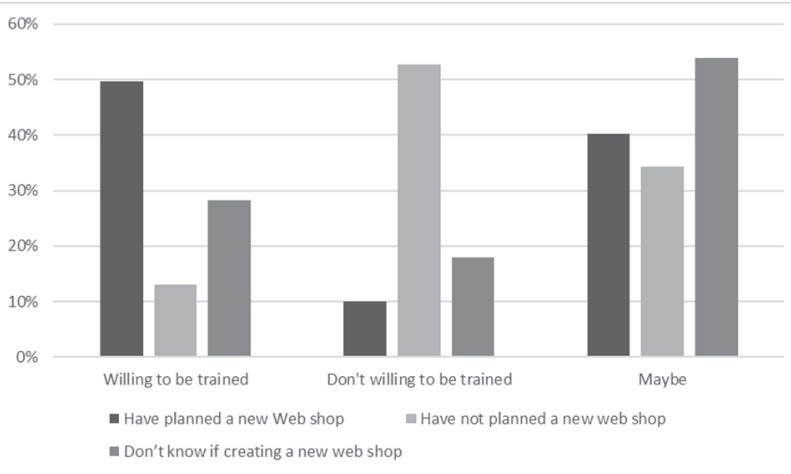

Figure 10 Employees willing to be trained (Q20) vs Planned new web shop

It is important to highlight that the more employees the company has the less interest in training courses the company shows (see Fig. 11). Maybe big companies think they already have enough resources and training options for their employees, so the free pilot courses of the project are not attractive for them.

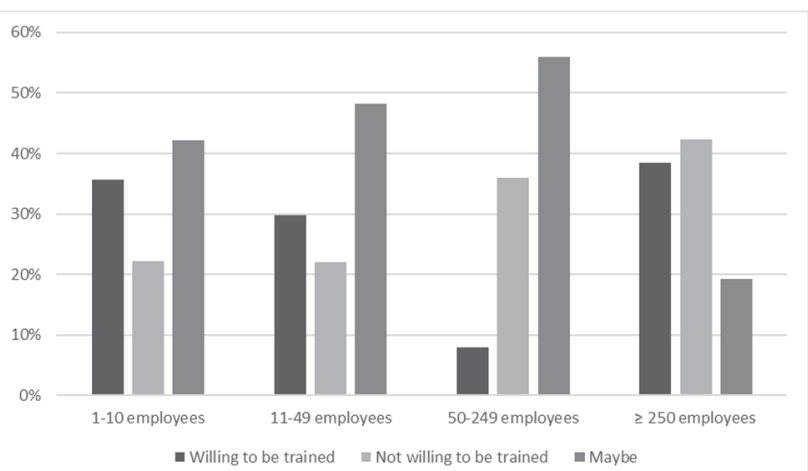

Figure 11 Size of company in number of employees (Q05) vs Employees willing to be trained (Q20)

Another relevant fact related to the previous one is that the bigger the annual turnover is, the less interest in training courses the company shows (see Fig. 12). The explanation could be similar: they do not need to find free resources and participate in pilot courses as they can get what they need with their own resources.

Fig. 13 shows the results collected from the question on training priorities (Q19). Since this one was an open question, we clustered the answers into 19 previously identified key areas. Most of the SMEs mostly request training on Marketing, Social Media and Technical
Solutions. As mentioned before, these answers gave the project the information to prepare a training curriculum with more emphasis on those areas, leaving the others as complementary ones.

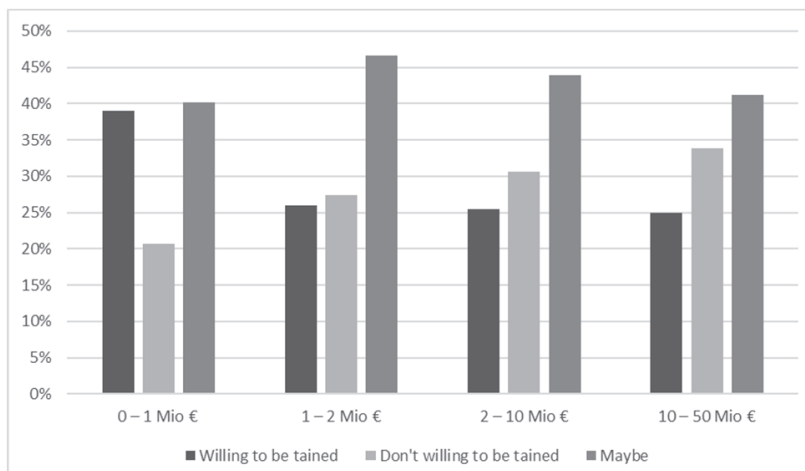

Figure 12 Annual turnover of the company (Q06) vs employees willing to be trained (Q20)

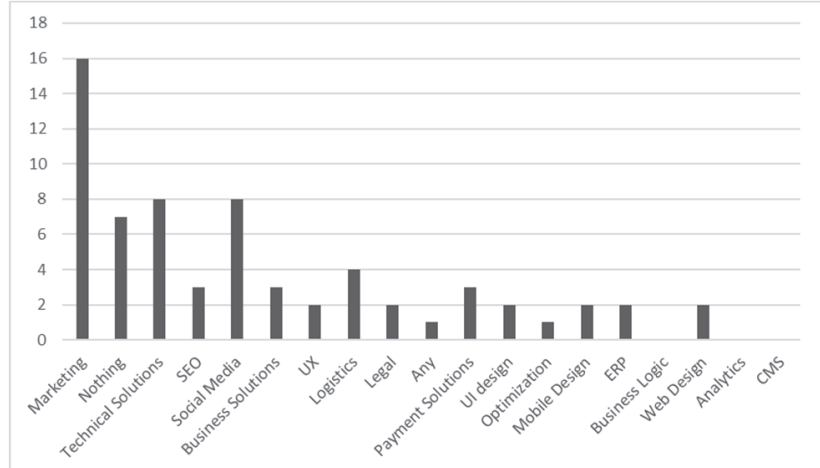

Figure 13 Kind of training in e-commerce that SMEs need (Q19)

Tab. 4 depicts a summary of what the analysis of results has provided to our research goals. We can see that all the RG have been successfully completed.

We performed a statistical analysis focused on the questions for which we allocated numerical scales according to our questionnaire design. We have found out that numeric data sets from answers to questions Q5, Q6, Q13, Q14 and Q15 follow a normal distribution after performing checks.

The correlation between them has also been studied by computing the Pearson correlation coefficient. From Tab. 5 it can be concluded that turnover (Q6) is related to the number of employees of the SME (Q5), but it is not related to the unique visitors per week (Q13), nor the percentage of visitors using a mobile device (Q14), nor the percentage of visitors driven from social media platforms (Q15). This shows that the success in turnover is simply linked to the size of company, or number of visitors (normal, mobile or from social networks) as this magnitude is not explicitly referred to the success in e-commerce and website popularity.

Another point we have explored is referred to questions Q13 and Q16: their histogram is depicted in Fig. 4 . They have a correlation coefficient of 0.28 , which means that the unique visitors per week are not related to the number of orders on the web shop. This suggests that the conversion rate is not very good in the sample of SME examined in our study and therefore suggesting there is still space for improvement in their m-commerce strategy. 
Table 4 Summary of the study

\begin{tabular}{|c|c|c|c|}
\hline \multirow{2}{*}{ Research goal } & \multicolumn{2}{|c|}{ Related questions } & \multirow[t]{2}{*}{ Findings } \\
\hline & $\begin{array}{l}\text { Respondents' } \\
\text { segmentation }\end{array}$ & Opinion & \\
\hline $\begin{array}{l}\text { RG1: To assess and characterize } \\
\text { the SMEs situation regarding the e- } \\
\text { commerce and m-commerce } \\
\text { context. }\end{array}$ & $\begin{array}{l}\text { Q07 } \\
\text { Q08 } \\
\text { Q02 } \\
\text { Q04 } \\
\text { Q12 }\end{array}$ & $\begin{array}{l}\text { Q03 } \\
\text { Q10 } \\
\text { Q06 } \\
\text { Q13 }\end{array}$ & $\begin{array}{l}\text { There are more web shops in B2C companies than in B2B } \\
\text { companies. } \\
\text { Percentage of web shops grows according to the size of the company } \\
\text { and according to the turnover. } \\
\text { Bigger companies and those with bigger turnover do not use third- } \\
\text { party web shops. } \\
\text { Most of the companies selling goods declared less than } 10 \% \text { of } \\
\text { turnover coming from e-commerce: those selling services declared } \\
\text { higher percentage of turnover from e-commerce. }\end{array}$ \\
\hline $\begin{array}{l}\text { RG2: To determine which factors } \\
\text { (size of the company, the type of } \\
\text { business, turnover, etc.) impact the } \\
\text { implementation of m-commerce } \\
\text { activities. }\end{array}$ & $\begin{array}{l}\text { Q14 } \\
\text { Q17 } \\
\text { Q16 } \\
\text { Q15 }\end{array}$ & $\begin{array}{l}\text { Q13 } \\
\text { Q10 } \\
\text { Q11 }\end{array}$ & $\begin{array}{l}\text { Products-based businesses are less involved in e-commerce than the } \\
\text { services-based ones. } \\
\text { SMEs which have an optimized web shop have more visitors and, } \\
\text { therefore, more possibilities to get orders. } \\
\text { Having an optimized web shop does not directly imply increasing } \\
\text { the number of orders per week from mobile users. } \\
\text { When the web shop is optimized, the percentage of visitors driven } \\
\text { by social media platforms increases. } \\
\text { Those SMEs that report more than } 40 \% \text { of mobile visitors driven by } \\
\text { social media are planning to build a new web shop. } \\
\text { The more unique customers who visit the web shop, the higher is the } \\
\text { number of SMEs which are planning to renovate their web shop. } \\
\text { The } 100 \% \text { of SMEs which report having more than } 20 \% \text { of the total } \\
\text { of orders per week coming from e-commerce are planning to } \\
\text { renovate their web shops. }\end{array}$ \\
\hline $\begin{array}{l}\text { RG3: To be aware of the needs and } \\
\text { requirements of SMEs to plan and } \\
\text { prepare training curricula. }\end{array}$ & $\begin{array}{l}\text { Q07 } \\
\text { Q11 } \\
\text { Q05 } \\
\text { Q06 }\end{array}$ & $\begin{array}{l}\text { Q19 } \\
\text { Q20 }\end{array}$ & $\begin{array}{l}\text { Most of the SMEs want their employees participate in the training } \\
\text { pilot independently of whether companies use a web shop or not. } \\
\text { Companies that were planning to build a new or different web shop } \\
\text { in the next } 12 \text { months are more interested in participating in free } \\
\text { training pilot courses. } \\
\text { The more employees the company has, the less interest in free pilot } \\
\text { training courses the company shows. } \\
\text { The bigger the annual turnover is, the less interest in free pilot } \\
\text { training courses the company shows. } \\
\text { Training needs are mainly focused on Marketing, Social Media and } \\
\text { Technical Solutions. }\end{array}$ \\
\hline
\end{tabular}

Table 5 Study of the correlation

\begin{tabular}{|c|c|}
\hline Questions & Pearson correlation coefficient \\
\hline Q5 - Q6 & 0.74 \\
\hline Q13 - Q6 & -0.11 \\
\hline Q14 - Q6 & -0.026 \\
\hline Q15 - Q6 & -0.14 \\
\hline Q16 - Q17 & 0.28 \\
\hline
\end{tabular}

\section{DISCUSSION}

Sample size and stratification are the main limitations of this study. A bigger and more diverse sample could have helped us to get a more precise idea of SME behaviour in the European context. However, the sample is wide and varied and the results could be considered relevant if we compare them with other similar studies. The variety of European countries is not complete, but it includes countries from different sizes, economic power and situation, etc. Similar published studies have considered smaller samples: for example, 108 respondents in Argentina [18], 237 respondents in Turkey [19], 210 respondents in Chile [13], 180 in Malaysia [25], 102 in USA [8], 163 in Kenya [28] and 129 in New Zealand [1]. In addition, all of them except $[8,1]$ use a general sample without focusing on SMEs that have already adopted ecommerce.

A different limitation could be the restricted geographical area (seven countries of the European Union), but it is more meaningful than the comparable studies of existing literature where all of them are focused on more restricted areas: e.g. a particular country [13], a state of a country [8] or even a city and its surrounding areas [18].

When designing the survey, there are some questions (e.g., turnover or number of visitors) that might be impacted by a lack of accuracy in the answers of companies' representatives. Nonetheless, we use wide options-range as solution, which is a commonly applied practice in other references of similar studies, e.g. [25]. This minimizes the risk of collecting responses which were not totally contrasted with the precise data of the company by the respondent.

When managing the open questions, one perceived limitation is that they do not guide respondents with predefined options, they require larger effort to process answers or there could be a loss of precision when clustering answers. Nevertheless, as there were no references explicitly facing $\mathrm{m}$-commerce training with a sound basis, we opted to include open questions: this way we tried to avoid influencing answers without having confirmed a widely accepted basis of relevant options for training areas.

In addition, one can feel that the percentage of companies not having a web shop is high when compared to those that have one. This might not be a limitation, as it is a mirror of the present companies' situation: moreover, we think that collecting the opinion of those companies is also important for our research to check how they are planning to enter the e-commerce and m-commerce activity.

Finally, the number of questions in the survey could be a limitation, as the respondents would have abandoned the 
questionnaire due to the time required for it. However, we have had a high number of companies that completed the survey, in reality a very high rate of completion and the high absolute number of responses when compared with similar studies in literature as explained before.

\section{CONCLUSIONS}

This article examines the situation of e-commerce and $\mathrm{m}$-commerce in SMEs in the European Union and tries to find out what are the most influential factors on the adoption of $\mathrm{m}$-commerce depending on the characteristics of the companies. An additional goal was also to determine the training needs for helping SMEs in developing their commerce potential through a set of free pilot courses developed along the study.

The analysis of results from an online survey responded by 674 SMEs representatives has provided relevant conclusions for the three research goals of our work. We have determined the numbers of basic parameters of the activity of SMEs in e-commerce and $\mathrm{m}$ commerce: existence of web shop, type of business activity, number of visitors, orders, percentage of total turnover, etc. We have also identified specific relations between some factors and the commerce results in companies (e.g. a web shop optimized for mobile users is connected to a higher number of visitors coming from social media) but we have also confirmed the absence of relations between others (e.g. web shops optimized for mobile visitors do not imply more orders). The information gathered through the survey has helped us in shaping a training curriculum for the courses where three topics have gained special weight: marketing, social media and technical solutions.

We have already planned future lines of action to progress in the study of $\mathrm{m}$-commerce in SMEs. One is a reshape of the survey before expanding it to more countries in Europe: one of the main points is open questions where the cumulated knowledge is now enabling the transformation into closed questions. We also want to exploit the feedback from the developed courses, getting the users' opinion to determine if we are in the right path for really addressing their needs of training. Finally, as the study was not particularly focused on the technical staff, we would like to address it in the light of the new European frameworks on ICT competences as e-CF and ESCO (European Commission, European Skills/Competences, qualifications and Occupations) to get the view of complementary training needs to guarantee a solid development of m-commerce for European SMEs.

\section{REFERENCES}

[1] Al-Qirim, N. (2007). The adoption of eCommerce communications and applications technologies in small businesses in New Zealand. Electronic Commerce Research and Applications, 6(4), 462-473. https://doi:10.1016/i.elerap.2007.02.012

[2] Bajad, R. A., Srivastava, M., \& Sinha, A. (2012). Survey on Mobile Cloud Computing. Engineering Sciences \& Emerging Technologies, 1, 8-19.

[3] Bolotaeva, V. \& Cata, T. (2010). Marketing opportunities with social networks. Journal of Internet Social Networking and Virtual Communities, 2010, 1-8. https://doi: 10.5171/2011.409860

[4] Chen, X. \& Lian, A. (2011). Service and P2P based secure media sharing in mobile commerce environments. Electronic Commerce Research, 11(1), 91-101. https://doi: 10.1007/s10660-010-9069-6

[5] Cozzarin, B. P. \& Dimitrov, S. (2016). Mobile commerce and device specific perceived risk. Electronic Commerce Research, 16(3), 335-354. https://doi.org/10.1007/s10660-015-9204-5

[6] Database-Eurostat, (2016) Digital economy and society. eCommerce. Obstacles for web sales.

[7] Ecommerce Foundation (2018). European Ecommerce Report 2018 Edition. Retrieved from https://www.ecommerce-europe.eu/research/ecommerceeurope-reports/

[8] Feindt, S., Jeffcoate, J., \& Chappell, C. (2002). Identifying success factors for rapid growth in SME e-commerce. Small business economics, 19(1), 51-62. https://doi.org/10.1023/A:1016165825476

[9] Frost \& Sullivan. (2015). The Global B2B E-commerce Market Will Reach 6.7 Trillion USD by 2020. Retrieved from: https://ww2.frost.com/news/press-releases/globalb2b-e-commerce-market-will-reach-67-trillion-usd-2020finds-frost-sullivan/

[10] Garbi, E. (2002). Alternative measures of performance for ecompanies: a comparison of approaches. Journal of Business Strategies, 19(1), 1-17.

[11] García, M. D. M. R., García-Nieto, J., \& Aldana-Montes J. F. (2016). An ontology-based data integration approach for web analytics in e-commerce. Expert Systems with Applications, 63, 20-34. https://doi.org/10.1016/j.eswa.2016.06.034

[12] Ghandour, A., Deans, K., Benwell, G., \& Pillai, P. (2008). Measuring ecommerce website success. ACIS 2008 Proceedings, 24.

[13] Grandón, E. E., Nasco, S. A., \& Mykytyn Jr, P. P. (2011). Comparing theories to explain e-commerce adoption. Journal of Business Research, 64(3), 292-298. https://doi.org/10.1016/j.jbusres.2009.11.015

[14] Harrison, D. A., Mykytyn Jr, P. P., \& Riemenschneider, C. K. (1997). Executive decisions about adoption of information technology in small business: Theory and empirical tests. Information systems research, 8(2), 171-195. https://doi.org/10.1287/isre.8.2.171

[15] Hawk, S. (2004). A comparison of B2C e-commerce in developing countries.Electronic Commerce Research, 4(3), 181-199. https://doi.org/10.1023/B:ELEC.0000027979.91972.36

[16] Jakimoski, K. (2014). Analysis of the Usability of Mcommerce Applications. International Journal of $U-\& E-$ Service, Science \& Technology, 7(6), 13-20. http://dx.doi.org/10.14257/ijunesst.2014.7.6.02

[17] Jennex, M. E., Amoroso, D., \& Adelakun, O. (2004). Ecommerce infrastructure success factors for small companies in developing economies. Electronic Commerce Research, 4(3), 263-286. https://doi.org/10.1023/B:ELEC.0000027983.36409.d4

[18] Jones, C., Alderete, M. V., \& Motta, J. J. (2014). Adopción del comercio electrónico en Micro, Pequeñas y Medianas empresas comerciales y de servicios de Córdoba, Argentina. Cuadernos de Administración, 29(50), 164-175. https://doi.org/10.25100/cdea.v29i50.52

[19] Kaynak, E., Tatoglu, E., \& Kula, V. (2005). An analysis of the factors affecting the adoption of electronic commerce by SMEs: Evidence from an emerging market. International marketing review, 22(6), 623-640. https://doi.org/10.1108/02651330510630258

[20] Kenny, R., Pierce, J., \& Pye, G. (2012, January). Ethical considerations and guidelines in web analytics and digital marketing: a retail case study. In AiCE 2012: Proceedings of 
the 6th Australian Institute of Computer Ethics conference 2012, 5-12. Australian Institute of Computer Ethics.

[21] Kim, Y. \& Srivastava, J. (2007, August). Impact of social influence in e-commerce decision making. Proceedings of the ninth international conference on Electronic commerce, 293-302. ACM. https://doi.org/10.1145/1282100.1282157

[22] Köster, A., Matt, C., \& Hess, T. (2016). Carefully choose your (payment) partner: How payment provider reputation influences m-commerce transactions. Electronic Commerce Research and Applications, 15, 26-37. https://doi.org/10.1016/j.elerap.2015.11.002

[23] Kshetri, N. (2007). Barriers to e-commerce and competitive business models in developing countries: A case study. Electronic commerce research and applications, 6(4), 443452. https://doi.org/10.1016/j.elerap.2007.02.004

[24] Kunešová, H. \& Eger, L. (2017). Evaluation and comparison of $\mathrm{B} 2 \mathrm{C}$ e-commerce intensity in EU member states. Ekonomie a Management, 20, 151-167. https://doi.org/10.15240/tul/001/2017-4-011

[25] Kurnia, S., Choudrie, J., Mahbubur, R. M., \& Alzougool, B. (2015). E-commerce technology adoption: A Malaysian grocery SME retail sector study. Journal of Business Research, 68(9), 1906-1918. https://doi.org/10.1016/j.jbusres.2014.12.010

[26] Leu, F. Y., Huang, Y. L., \& Wang, S. M. (2015). A Secure M-Commerce System based on credit card transaction. Electronic Commerce Research and Applications, 14(5), 351-360. https://doi.org/10.1016/j.elerap.2015.05.001

[27] Li, M., Dong, Z. Y., \& Chen, X. (2012). Factors influencing consumption experience of mobile commerce: a study from experiential view. Internet Research, 22(2), 120-141. https://doi.org/10.1108/10662241211214539

[28] Mutua, J., Oteyo, I. N., \& Njeru, A. W. (2013). The extent of e-commerce adoption among small and medium enterprises in Nairobi, Kenya. International Journal of Business and Social Science, 4(9).

[29] Nilashi, M., Ibrahim, O., Mirabi, V. R., Ebrahimi, L., \& Zare, M. (2015). The role of Security, Design and Content factors on customer trust in mobile commerce. Journal of Retailing and Consumer Services, 26, 57-69. https://doi.org/10.1016/j.jretconser.2015.05.002

[30] ONTSI (2012). Tecnologías de la Información y las Comunicacionesen las PYMES y grandesempresasespañolas, 2012. Retrieved from: https://www.ontsi.red.es/ontsi/es/estudios-e-informes/lastic-en-las-empresas-y-microempresas-espanolas-edicion2012

[31] ONTSI (2016). Estudio sobre Comercio Electrónico B2C $2015 . \quad$ Retrieved from: https://www.ontsi.red.es/ontsi/sites/ontsi/files/Informe $\% 20$ B2C\%202015\%20\%28Edici\%C3\%B3n\%202016\%29.pdf

[32] Öztürk, Ö. \& Rızvanoğlu, K. (2013, July). M-Commerce usability: an explorative study on turkish private shopping apps and mobile sites. International Conference of Design, User Experience, and Usability, 623-630.Springer, Berlin, Heidelberg. https://doi.org/10.1007/978-3-642-39253-5_69

[33] Rahayu, R. \& Day, J. (2017). E-commerce adoption by SMEs in developing countries: evidence from Indonesia. Eurasian Business Review, 7(1), 25-41. https://doi.org/10.1007/s40821-016-0044-6

[34] Shao Yeh, Y. \& Li, Y. M. (2009). Building trust in mcommerce: contributions from quality and satisfaction. Online Information Review, 33(6), 1066-1086. https://doi.org/10.1108/14684520911011016

[35] Sharma, S. \& Gutiérrez, J. A. (2010). An evaluation framework for viable business models for m-commerce in the information technology sector. Electronic Markets, 20(1), 33-52. https://doi.org/10.1007/s12525-010-0028-9

[36] Simpson, M. \& Docherty, A. J. (2004). E-commerce adoption support and advice for UK SMEs. Journal of small business and enterprise development, 11(3), 315-328. https://doi.org/10.1108/14626000410551573

[37] Stockdale, R. \& Standing, C. (2006). A classification model to support SME e-commerce adoption initiatives. Journal of small business and enterprise development, 13(3), 381-394. https://doi.org/10.1108/14626000610680262

[38] Taylor, M. J., Mcwilliam, J., England, D., \& Akomode, J. (2004). Skills required in developing electronic commerce for small and medium enterprises: case based generalization approach. Electronic Commerce Research and Applications, 3(3), 253-265. https://doi.org/10.1016/j.elerap.2004.04.001

[39] Todd, P. R. \& Javalgi, R. R. G. (2007). Internationalization of SMEs in India: Fostering entrepreneurship by leveraging information technology. International journal of emerging markets, 2(2), 166-180. https://doi.org/10.1108/17468800710739234

[40] Wang, T. C. \& Lin, Y. L. (2009). Accurately predicting the success of B2B e-commerce in small and medium enterprises. Expert Systems with Applications, 36(2), 27502758. https://doi.org/10.1016/j.eswa.2008.01.033

[41] Wu, J. H. \& Wang, Y. M. (2006). Development of a tool for selecting mobile shopping site: A customer perspective. Electronic Commerce Research and Applications, 5(3), 192200. https://doi.org/10.1016/j.elerap.2005.09.004

[42] Wymer, S. A. \& Regan, E. A. (2005). Factors influencing ecommerce adoption and use by small and medium businesses. Electronic markets, 15(4), 438-453. http://doi.org/10.1080/10196780500303151

[43] Zarmpou, T., Saprikis, V., Markos, A., \& Vlachopoulou, M. (2012). Modeling users' acceptance of mobile services. Electronic Commerce Research, 12(2), 225-248. https://doi.org/10.1007/s10660-012-9092-x

\section{Contact information}

Luis FERNÁNDEZ SANZ, PhD Associate Professor

University of Alcalá, Department of Computer Sciences,

Edificio Politécnico, Campus Universitario, Ctra. Barcelona Km 33.6, 28871

Alcalá de Henares (Madrid), Spain

E-mail: luis.fernandezs@uah.es

\section{Josefa GÓMEZ PÉREZ, PhD, Assistant Professor}

University of Alcalá, Department of Computer Sciences,

Edificio Politécnico, Campus Universitario, Ctra. Barcelona Km 33.6, 28871

Alcalá de Henares (Madrid), Spain

E-mail: josefa.gomez@uah.es

\section{Ana CASTILLO-MARTINEZ, PhD, Assistant Professor}

(Corresponding author)

University of Alcalá, Department of Computer Sciences,

Edificio Politécnico, Campus Universitario, Ctra. Barcelona Km 33.6,

28871 Alcalá de Henares (Madrid), Spain

E-mail: ana.castillo@uah.es

Sanjay MISRA, PhD Full Professor

Covenant University,

KM. 10 Idiroko Road, Canaan Land, Ota, Ogun State, Nigeria

Atilim University,

Kizilcasar Mahallesi, 06830 Incek Golbasi Ankara, Turkey

E-mail: sanjay.misra@covenantuniversity.edu.ng 